\title{
Medical Mistrust and Enduring Racism in South Africa
}

\author{
Tessa Moll $\mathbb{1}$
}

Received: 29 April 2020 / Accepted: 30 November 2020 / Published online: 5 January 2021

(C) Journal of Bioethical Inquiry Pty Ltd. 2021

\begin{abstract}
In this essay, I argue that exploring institutional racism also needs to examine interactions and communications between patients and providers. Exchange between bioethicists, social scientists, and life scientists should emphasize the biological effectsmade evident through health disparities-of racism. I discuss this through examples of patient-provider communication in fertility clinics in South Africa and the ongoing COVID-19 pandemic to emphasize the issue of mistrust between patients and medical institutions. Health disparities and medical mistrust are interrelated problems of racism in healthcare provision.
\end{abstract}

Keywords Race · South Africa - Medical mistrust . COVID-19 $\cdot$ Racialized culturalism

In her essay arguing that bioethicists be at the forefront of conversations with life scientists on race, philosopher Camisha Russell (2021) outlines three ways that race is often framed in both biomedical and lay circles. These are 1) "race science," the largely discredited idea that race has a basis in the natural world and is therefore ultimately "verifiable by science," 2) race as a social construct, meaning that race emerges from the social meanings that are gathered from "natural physiological

T. Moll $(\bowtie)$

Alfred Deakin Institute for Citizenship and Globalization, Deakin University, 221 Burwood Hwy, Burwood, VIC 3125, Australia e-mail: tessa.moll@ deakin.edu.au differences," 3) race as a driver of historical progress that underlies differing teleologies to a so-called developed modernity (what white nationalists often argue). In her fourth offer, Russell contends that, at its most fruitful, thinking with race as a technology allows us to move beyond the question of what race $i s$ and instead ask what race does.

In my role as an anthropologist, my fieldwork brought me not to the researchers of life science but their clinical practitioners, in the tense and tender interactions between clinical medicine and patients in South African fertility clinics. These are often overlooked moments in thinking about race in the life sciences; the legacy of "race science" and notions of genetic difference looms long and large. But genetics is not the only space for locating ideas of racial difference. As Anne Pollock argues:

Race in biomedicine does not originate in the science and filter down to the doctors' offices; neither does it simply filter up. It does slightly different work in each sphere, but gains its durability through its capacity to travel between them. $(2012,5)$

Less a question of its "realness" in office spaces, race certainly has very real effects. These effects I contextualize and embed in South Africa. As Russell has previously argued (2016), voices on the margin need to also be brought forth to the centre of philosophical and bioethical discussions of justice. Thinking about legacies and lessons and manifestations of race and bioethics need not always centre U.S. histories. In those moments 
in South Africa like the vignette below, race is a category that shapes all manner and measure of interactions, decisions, and engagement between staff and patients. While life scientists have done well to argue against a biological basis for racialized difference, I, like Russell, encourage them to recognize the biological effects of racism. These include, but are not limited to, the ongoing mistrust between medical institutions and many communities and the enduring health disparities emerging from racialized political economy.

During my fieldwork in fertility clinics, I often sat with clinic staff as they explained to patients how IVF worked and guided them through the key decisions that they would have to make in the coming weeks. Despite spending three months at one clinic, I encountered only a single black couple coming in for IVF. Like many spaces of post-apartheid life, fertility clinics in South Africa are deeply segregated spaces. While white people make up less than 10 per cent of the population, the vast majority of IVF patients and all the professional medical staff that I met were white. ${ }^{1}$ Patients were more diverse, including some patients from nearby Angola, Namibia, and Zimbabwe, but the majority were also white. No doubt the high cost of IVF cycles in private clinics - and twelve of fifteen fertility clinics in South Africa are private - becomes a de facto form of racial segregation as wealth remains cloistered among a persistently white local elite.

A black couple came in one day searching for biomedical solutions for their problem - married for two years and they had yet to fall pregnant. Both had children from previous partnerships but desired a child together. Originally from Mthata, a regional hub in the Eastern Cape, the couple now lived near Cape Town, where the man, Fundani, ran and owned a shebeen, an informal local tavern. Estie, the clinic staff member, came to explain IVF and ask them questions about their relationship, understanding of the process, and experience of trying to conceive. At least that would be the typical procedure I had seen from her on several occasions. This case began similarly but quickly veered into discourses of racialized culturalism that endure in white spaces of South Africa. While race science - the notion of race being a biologically-rooted form of difference-

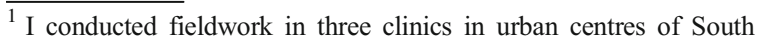
Africa. The racial homogeneity was and is not the case for all clinics across the country; however, fertility medical staff remain predominantly white. For instance, at the time of my fieldwork in 2015-2016, all the physicians in Cape Town were white.
}

provided a form of "scientific legitimacy" to the apartheid regime, culture was also a significant fulcrum of difference in the logic of South African white supremacy (Dubow 1995). This too was backed with "science," as volkekunde anthropologists contributed the theoretical backing for social segregation along demarcations of culture (Sharp 2007). Racialized culturalism refers to the ways that "culture" emerges as a rationale for racial difference, a discourse I had all too often been privy to as a white person living in South Africa today.

In the clinic, as I observed, Estie, who was white, asked Fundani and Colleen how long they had been "struggling to fall pregnant." Two years, they saidsince their wedding. Then, Estie continued, "In black culture, it's much more difficult when you want a baby; your wife can be an outcast. But it's different in your case because you both have children. In your culture, you must have a child." They nodded along as she spoke. Estie continued, asking about their relationship; "No fights?" No, Fundani and Colleen said, no fights. "Do you have enough money to raise the child?" Fundani nodded. "How much was lobolo ${ }^{2}$ ? How many cattle?" Fundani chuckled but didn't answer. "Were you married traditionally?" Yes, Colleen said. "Do you have just the one wife or more than one wife?" He said just one wife. Estie asked what he did, and he said he sold beer. "You have a shebeen? Are you a drinker? Alcohol can hurt those sperms that we need for making the baby." He said that he didn't drink, and his wife, Colleen, reiterated, "No, no, he doesn't drink, he's a good man." These are questions and allusion that I never saw lobbed at white couples.

When it came time for the couple to make some medical decisions-How did they feel about freezing extra embryos? Did they want to use the more expensive incubator?-Fundani asked the medical professionals to leave the room and instead asked me, the outsider anthropologist, what I thought they should do. I was, and am, not a medical professional; I couldn't offer medical advice and was clear about that. He asked why the extra cost for freezing? I explained why freezing costs money-liquid nitrogen, storage space — but also why it can be beneficial to have frozen embryos rather than "start from scratch." He seemed satisfied with my explanations - and my limitations as someone without

\footnotetext{
${ }^{2}$ Lobolo is the customary payment from a male partner to the women's family as part of the marriage process. Cattle are the main sources and denominations of payment.
} 
medical training. After the couple left, I spoke with the medical staff about the situation. "We should have a translator here next time," mused Estie. Estie thought it was an issue of language. I thought it was an issue of trust, and one that went both ways. In my reading, Estie did not trust Fundani and Colleen. Their racial difference marked them as suspect and having questionable motives for parenthood and family relations, and she suspected they lacked in resources to pay for treatment and care for a potential child. In response, Fundani and Colleen clearly did not trust Estie, nor the other medical staff. In my reading, they felt the mistrust and in turn worried that were being potentially duped - that the clinic staff were after their money rather than helping them with their problem. Ironically, I believe that Estie's line of questioning came from a place of concern with providing what some medical programmes refer to as “culturally competent care" (see Jenks 2010).

One often thinks of mistrust in medical institutions as arising from specific and infamous moments of unethical research. For instance, in the introduction to their special issue on public trust and expert knowledge, Camporesi, Vaccarella, and Davis (2017) reference the Tuskegee Syphilis Study in the United States, where doctors knowingly withheld treatment for six hundred black men. In South Africa, we have fresh in our minds the apartheid-era Project Coast and the plans (recounted in the late 1990s Truth and Reconciliation Commission) of biological warfare against the black population using, but not limited to, the dissemination of anthrax, the purposeful deployment of cholera in high-density neighbourhoods, and the use of sterilizing oral contraception (Fassin 2015). And yet the public are also comprised of people, each with their individual tales of doctor-patient interactions, and many like Fundani and Colleen.

The need for a thinking about race and the institutions of life sciences has become ever more urgent. The world has changed immensely in the mere weeks since Russell set out her call for collaboration between bioethics and life sciences on the lessons of race. In those weeks, COVID-19 has, as of this writing, emerged in nearly three million confirmed cases, and claimed the lives of at least several hundred thousand. ${ }^{3}$ I, along with nearly a third of the world, am under lockdown, connected to friends, family, and news of the world via

\footnotetext{
${ }^{3}$ The rate of infection still astonishes me. How woefully out-of-date this number will be by the time this essay goes to press.
}

WhatsApp and Zoom. While our intimate connections are increasingly framed as threats in themselves, the information connections flourish, allowing for a different kind of threat. State health officials and researchers' peer-reviewed work sits side by side with the ramblings of the U.S. president and other dubious sources. Our present condition flattens credibility, confusing questions of validity and expertise. In South Africa, where I write and reside, I have read online that drinking hot tea can kill the virus. There is an ongoing theory about its source involving the Chinese state and $5 \mathrm{G}$ installations. A member of parliament wrote to President Cyril Ramaphosa asking for clarification on why Bill Gates had been in Cape Town earlier in the year (for a charity tennis match), citing rumours that the billionaire had come to discuss secret vaccine trials in Africa.

Like many rumours and theories, the latter comes with scaffolds of present and historical truths. In early April, two French scientists discussed on television whether to test a COVID vaccine on Africans. After public denouncements, they attempted to clarify that they merely wanted to ensure that Africa was included in vaccine trials. As Fiona Ross (2020) writes, "We do not come to this disease as tabula rasa." This is true in more ways than one. Many South Africans come to COVID with durable legacies (see Stoler 2016) of apartheid-era Project Coast and contemporary enduring and daily experiences of racism. Many South Africans know well the biopolitical stratifications of life and how medicine has often worked alongside those stratifications, if not sedimented in them.

When the virus first came to South Africa, many suggested that it only affected white people. This was bolstered by the fact that the first cases were all white people, those coming from holidays abroad. As Adia Benton (2020) describes, "Viruses move in bodies, and the freedom of certain bodies, certain people, to move across borders needs to be acknowledged." This is an acknowledgement to counter the common narrative that viruses know no border, no class, no race. Viruses, this narrative goes, reduce us all to mere biology: deracialized, decontextualized biology. The statistics would beg to differ. In the United States, early figures from the Centers for Disease Control (CDC) show that 33 per cent of COVID hospitalizations were among black patients, despite them comprising 18 per cent of the population in the catchment area. Health disparities, an effect of racism and economic stratifications, underly the differing co-morbidities of hypertension, obesity, 
and chronic lung disease (CDC 2020). This is certainly in the minds of South Africa's political and public health leaders, who have implemented one of the strictest lockdowns in the world. Efforts to slow the spread approach dry tinder: a population largely impoverished by decades of white supremist rule, many immunosuppressed from HIV/AIDS, one of the highest rates of tuberculosis, and living in high-density neighbourhoods. The understanding that the social emerges in biology, or what Margaret Lock (1993) referred to as "local biologies," has gained greater traction in recent years. Epigenetics research now suggests the enduring impression of social stratification in genetic expression (Krieger 2000; Kuzawa and Sweet 2009). Legacies of racism may now be etched in bodies in ways surprisingly material and frustratingly durable (Meloni 2017).

These twinned legacies - mistrust of scientific expertise and institutions and enduring racial health disparities - are of course interrelated. They come from moments that make headlines and moments that do not. I do not know if Fundani and Colleen ever came back for IVF treatment or if they ever became pregnant. They certainly understood the roots of the treatment they experienced at the clinic and, I surmise, felt they weren't getting proper care as a result. Regardless of the ontological status of race in that moment, whether it came in the form of racialized culturalism or scientific racism, the impacts of it were immediate. The current global pandemic brings the need for bioethicists, social scientists, and life scientists to work collaboratively and reflexively to recognize the complicated place of race, both historically and in the present, to ever greater urgency. Simultaneously to that, we also need to reflect on whether we (and here I include anthropologists like myself) deserve any such trust to have these conversations and to have them well. Many disciplines, life and social sciences alike, have legacies that long need understanding, reflecting, and ideally upending in order to move forward with this critical work.

\section{References}

Benton, A. 2020. Border promiscuity, illicit intimacies, and origin stories: Or what Contagion's bookends tell us about new infectious diseases and a racialized geography of blame. Somatosphere, March 6. somatosphere. net/forumpost/border-promiscuity-racialized-blame/. Accessed November 28, 2020.

Camporesi, S., M. Vaccarella, and M. Davis. 2017. Investigating public trust in expert knowledge: Narrative, ethics, and engagement. Journal of Bioethical Inquiry 14(1): 23-30.

CDC (Centers for Disease Control). 2020. Hospitalization rates and characteristics of patients hospitalized with laboratoryconfirmed coronavirus disease 2019. Morbidity and Mortality Weekly Report 69(15): 458-464.

Dubow, S. 1995. Scientific racism in modern South Africa. Cambridge: Cambridge University Press.

Fassin, D. 2015. Adventures of African nevirapine: The political biography of a magic bullet. In Para-States and Medical Science: Making African Global Health, edited by P. Geizler, 333-353. Durham, NC: Duke University Press.

Jenks, A. 2010. What's the use of culture? Health disparities and the development of culturally competent healthcare. In What's the use of race? Modern governance and the biology of difference, edited by I. Whitmarsh and D.S. Jones, 207224. Cambridge, USA: MIT Press.

Krieger, N. 2000. Refiguring "race": Epidemiology, racialized biology, and biological expressions of race relations. International Journal of Health Services 30(1): 211-216.

Kuzawa, C.W., and E. Sweet. 2009. Epigenetics and the embodiment of race: Developmental origins of US racial disparities in cardiovascular health. American Journal of Human Biology 21(1): 2-15.

Lock, M. 1993. Encounters with aging: Mythologies of menopause in Japan and North America. Berkeley: University of California Press.

Meloni, M. 2017. Race in an epigenetic time: Thinking biology in the plural. The British Journal of Sociology 68(3): 389-409.

Pollock, A. 2012. Medicating race: Heart disease and durable preoccupations with difference. Durham, USA: Duke University Press.

Ross, F. 2020. Of soap and dignity in South Africa's lockdown. Corona Times, April 8. https://www.coronatimes.net/soapdignity-south-africa-lockdown/. Accessed November 28, 2020.

Russell, C. 2021. Bioethicists should be helping scientists think about race. Journal of Bioethical Inquiry 18(1). https:// doi.org/10.1007s11673-020-10068-x. 2016. Questions of race in bioethics: Deceit, disregard, disparity, and the work of decentering. Philosophy Compass 11(1): 43-55.

Sharp, J. 2007. The roots and development of Volkekunde in South Africa. Journal of Southern African Studies 8(1): 1636.

Stoler, L.A. 2016. Duress: Imperial durabilities in our times. Durham, USA: Duke University Press.

Publisher's note Springer Nature remains neutral with regard to jurisdictional claims in published maps and institutional affiliations. 